\title{
Investigating Brand Switching on Cosmetics Products: A Case Study of Nu Skin
}

\author{
Mayong Ajiwinanto ${ }^{1 *}$; Megawati Simanjuntak ${ }^{2}$; Hendri Tanjung ${ }^{3}$ \\ ${ }^{1}$ School of Business, IPB University \\ Jln. Raya Pajajaran, Bogor 16128, Indonesia \\ ${ }^{2}$ Department of Family and Consumer Sciences, Faculty of Human Ecology, IPB University \\ Jln. Raya Dramaga, Bogor 16680, Indonesia \\ ${ }^{3}$ Post Graduate School, Ibn Khaldun University \\ Jln. Sholeh Iskandar, Bogor 16162, Indonesia \\ 1'mayongajiwinanto@gmail.com; ${ }^{2}$ mega_juntak@apps.ipb.ac.id; ${ }^{3}$ hendri.tanjung@gmail.com
}

Received: $24^{\text {th }}$ January 2021/ Revised: $2^{\text {th }}$ March 2021/ Accepted: $5^{\text {th }}$ April 2021

How to Cite: Ajiwinanto, M., Simanjuntak, M., \& Tanjung, H. (2021). Investigating Brand Switching on Cosmetics Products: A Case Study of Nu Skin. Binus Business Review, 12(3), 241-254. https://doi.org/10.21512/bbr.v12i3.6989

\begin{abstract}
The rapid development of cosmetics industry and the high competition in cosmetics market in Indonesia impact consumers. The market has many available choices of cosmetics products, and this situation causes many consumers to switch brands. The research aimed to analyze the suitability of Sharia about cosmetics products from $\mathrm{Nu}$ Skin and the factors that influenced the brand switching of the cosmetics product with multi-level marketing. The research applied a quantitative and descriptive approach. Data collection from respondents was carried out with a structured questionnaire. The respondents were consumers who had bought and used Nu Skin products. Around 150 respondents were selected through the purposive sampling method. Then, the researchers used the LISREL software. The connection between the variables was investigated by Structural Equation Modeling (SEM). The findings indicate that Word of Mouth (WOM) and marketing mix significantly influence the brand image of the cosmetics products. Similarly, religiosity and marketing mix have a significant influence on brand attitude. Then, brand image and brand attitude have a significant effect on brand switching. However, religiosity has no significant effect on brand switching. For marketing practitioners, the results can be considered in terms of marketing strategy in consumers' habits of accessing social media to read product reviews from their friends who have used Nu Skin products before. The more people review and recommend the products to others, the higher the consumers' interest is in buying Nu Skin products, and the smaller the intensity is involved in brand switching behavior. The research offers a new insight regarding the influencing factors of brand switching of halal cosmetics products through multi-level marketing.
\end{abstract}

Keywords: brand switching, cosmetics product, multi-level marketing

\section{INTRODUCTION}

The cosmetics industry is one of the fastestgrowing sectors in Indonesia and has consistently recorded increasing growth in recent years. The cosmetics market in Indonesia from 2010 to 2019 has increased by an average of seven percent per year. The percentage is predicted to continue to increase until 2023 (Cekindo, 2019). The value of the growth of the cosmetics industry in Indonesia can be seen in Figure 1.
The growth in sales volume of cosmetics industry is boosted by the rising demand from the middle class. The number of lucrative markets in Indonesia is 267 million people, with a female population as cosmetics users reaching 126,8 million people and around $68 \%$ are productive women. This sizable demand from the middle class of Indonesian women is also driven by the increasing awareness of certain segments of their self-image and dress styles (Global Business Guide Indonesia, 2016). The rapid development of the cosmetics industry has led to greater competition for 


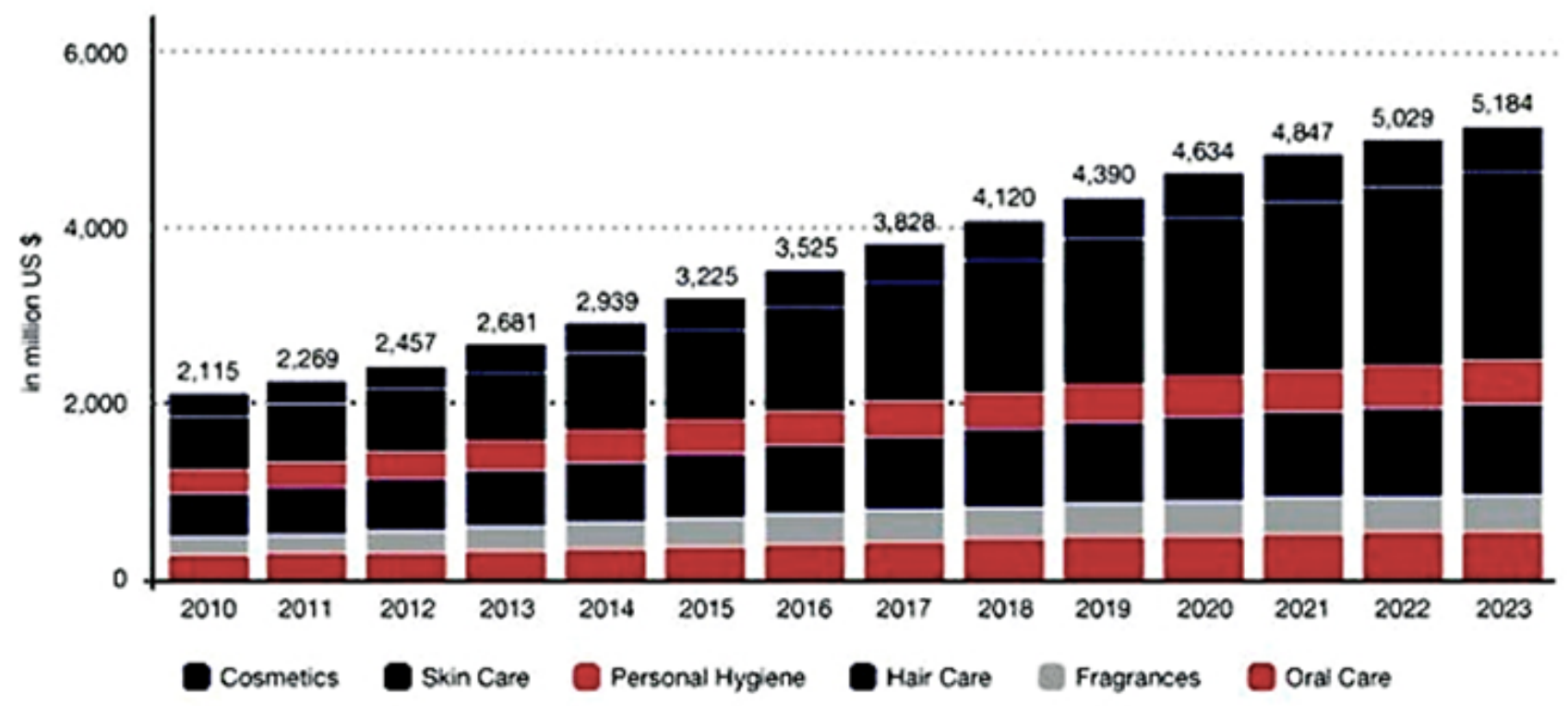

Figure 1 The Growth of the Cosmetics Market in Indonesia

(Source: Cekindo, 2019)

cosmetics products, especially through tiered direct selling. Based on income, the ranking of cosmetic products sold under a tiered direct sales system can be seen in Figure 2 (Direct Selling News (DSN), 2019). Cosmetics products from the Infinitus had an increase in income by an average of $13 \%$ per year, increasing by ranking in 2019 from the fourth to the third and beating the revenue of Vorwerk. Meanwhile, the revenue of $\mathrm{Nu}$ Skin brand cosmetic products increased in revenue in 2018 by $\$ 2,208$ billion to $\$ 2,28$ billion in 2019. The impact of the competitive cosmetics product for consumers is the availability of many choices. This situation causes many consumers to switch brands. Moreover, the cause of brand switching by consumers also relies on the need for variety, dissatisfaction, and problem-solving strategies.

The growing obsession for beauty among women has led to massive growth in the cosmetics industry. This phenomenon has resulted in many cosmetics products on the market. Moreover, advances in information technology have increasingly added the intensity of competition for cosmetics products. As a result, cosmetics products are easily introduced to consumers.

Furthermore, religion also influences consumers' decision-making when buying products or services. Religion is an essential element for understanding consumers' behavior because of restrictions on the consumption of certain elements. Then, religiosity is considered an essential indicator in every decision that directs someone to behave legally and ethically (Elaziz \& Kurt, 2017). Religiosity has a role in influencing consumers' purchasing decisions. For this reason, it is necessary to understand the effects of religiosity in formulating promotion strategies and marketing halal cosmetics products in Muslim majority countries. Muslim consumers are unique in the sense that they must comply with the halal requirements specified in Islamic teachings. Halal cosmetics are different from ordinary cosmetics because halal cosmetics must not contain traces of pork by-products and their derivatives, alcohol, and other prohibited ingredients according to Islamic guidelines. Halal is a concept in Islamic teachings that is a recipe for allowed and prohibited goods for Muslim consumption (Ishak, Omar, Khalid, Ghafar, \& Hussain, 2019).

Muslims who use cosmetics products tend to consider choosing products that are declared halal compared to products that have not been declared halal by the competent authority. This situation will undoubtedly impact the high level of consumers who care about the halal nature of the products they buy. The characteristics of halal cosmetics consumers have an outstanding level of education, namely Diploma and Bachelor's degree who work as private employees. Most consumers belong to the middle-class customer segment with a fairly regular frequency of purchasing cosmetics, namely 6 to 11 purchases per year (Ishak et al., 2019). In consumers' purchasing patterns, there is a unique phenomenon that most consumers will continue to buy the same brand even though the price of the product brand has increased by considering the quality (Septiani \& Indraswari, 2018). 


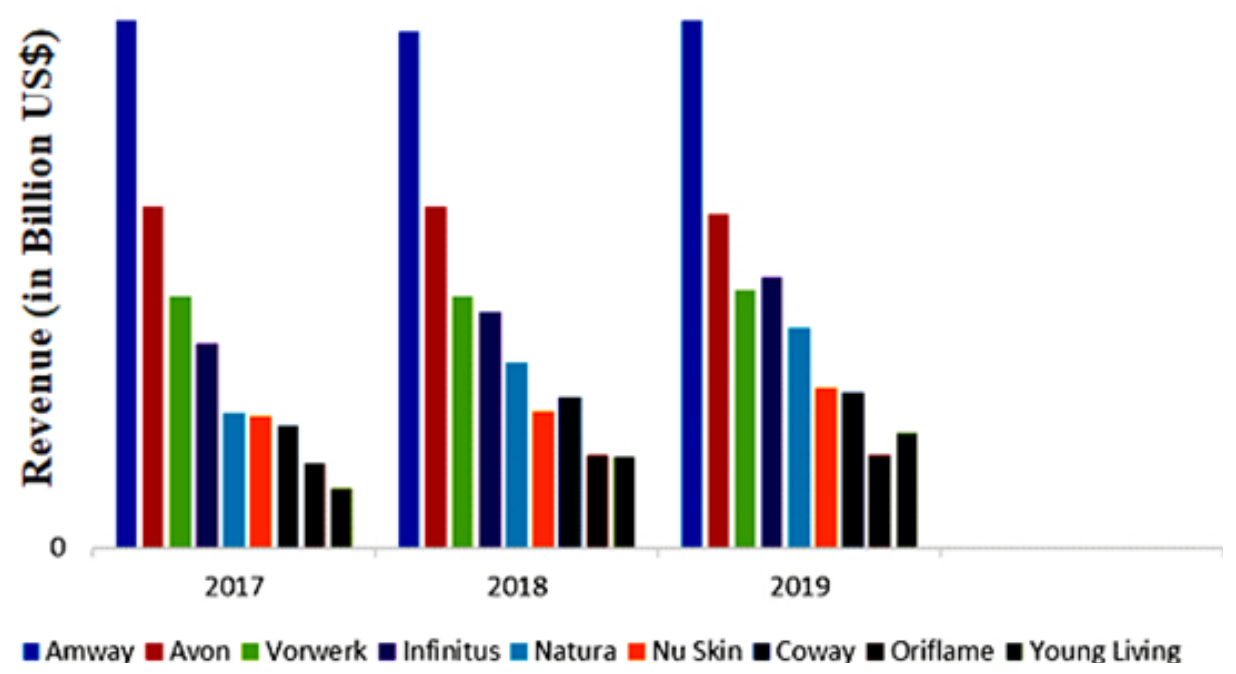

Figure 2 Cosmetics Brand Revenue with Multi-Level Marketing

The other factors that trigger the intensity of brand switching are consumers' dissatisfaction with product or service performance. Decision-makers often struggle to assess the extent of consumers' dissatisfaction in online product reviews. When consumers use causality words and display future intentions in negative online reviews, managers underestimate their dissatisfaction (Antioco \& Coussement, 2018). Marketers should start creating unique and superior consumer experiences on an ongoing basis to encourage the consumers to spread positive news about their experiences with brands on social media. It will lead to the creation of a support base that increases the effectiveness of social media communication and, consequently, the efficiency of promotional campaigns (Sözer, 2019).

Apart from religiosity, dissatisfaction, and seeking variations, another factor driving consumers' brand switching is Word of Mouth (WOM). The millennial generation's purchase decision-making is faster than the previous generation because of access to information that can be obtained quickly. This decision-making is influenced by WOM or other people's recommendations, such as friends who have used the products through various social platforms (Moreno, Lafuente, Carreón, \& Moreno, 2017). Moreover, millennials have very high brand awareness but low brand loyalty. Hence, the habit of switching brands of the millennial generation is common because this generation has a low level of loyalty. Millennials are more reactive to social, cultural, economic, and political changes. Their buying behavior is sustainable development (Moreno et al., 2017). Consumers will abandon stimulation and activate variety seeking (the need to look for variations), leading to category shift and brand switching (Khasanah \& Cahya, 2018).

One of the promotion strategies for halal cosmetics products with multi-level marketing is
WOM. It is a promotion in the form of recommendations about the goodness of a product. This communication is carried out by consumers who have made a purchase. They tell their experiences about the product to others, so they indirectly do promotions that can attract the interests of other consumers. WOM can occur naturally among everyday consumers through telecommunications media and direct verbal contact. Like the marketing mix strategy that must beformulated in advance, the company is also tasked with creating the WOM effect through the brand image of the offered cosmetics products. Hence, a positive WOM can happen automatically among consumers. It is very relevant when looking at the effectiveness of WOM compared to other promotional media in addition to the existing marketing mix programs. If the consumers are satisfied, they will show an excellent opportunity to make a repeat purchase (Harun, Mahmud, Othman, Ali, \& Ismael, 2020). Therefore, companies need to carry out a proper and effective marketing strategy. They should consider brand attitudes, brand image, and brand loyalty through WOM. By knowing the consumers' brand attitude, the companies can determine the marketing strategy and improve the marketing activities to increase market share and total sales.

Based on the theoretical study described, the conceptual framework in the research is shown in Figure 3. Then, the research hypotheses based on the conceptual framework are as follows.

H1 : WOM has a significant effect on brand attitude.

H2 : WOM has a significant impact on brand image.

H3 : Marketing mix has a significant effect on brand attitude.

H4 : Marketing mix has a significant effect on brand image.

H5 : Religiosity has a significant effect on brand attitude. 


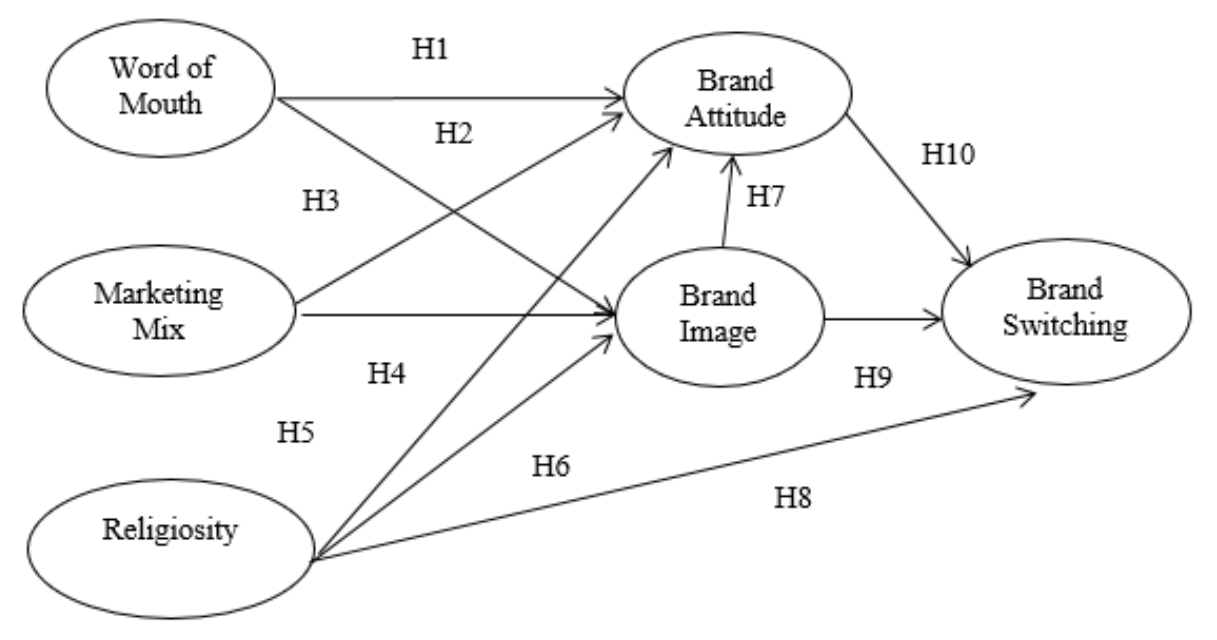

Figure 3 Conceptual Framework

Table 1 The Research Variables and Indicators

\begin{tabular}{|c|c|c|c|}
\hline Variable & Operational Definition & Indicator & Indicator Code \\
\hline WOM & $\begin{array}{l}\text { Exchange of ideas, thoughts, and } \\
\text { comments between two or more } \\
\text { consumers. Neither of them is the } \\
\text { marketer. }\end{array}$ & \begin{tabular}{|l|} 
Social drivers \\
Emotional drivers \\
Functional drivers
\end{tabular} & $\begin{array}{l}\text { WOM1 } \\
\text { WOM2 } \\
\text { WOM3 }\end{array}$ \\
\hline Price & Income-generating elements. & $\begin{array}{l}\text { The price of the offered product } \\
\text { Competitive price } \\
\text { Products according to the offered price } \\
\text { Price in accordance with product quality }\end{array}$ & $\begin{array}{l}\text { BP1 } \\
\text { BP2 } \\
\text { BP3 } \\
\text { BP4 }\end{array}$ \\
\hline Product & $\begin{array}{l}\text { Something that is offered and felt by } \\
\text { consumers. }\end{array}$ & $\begin{array}{l}\text { Composition } \\
\text { Technology } \\
\text { Halal label } \\
\text { Cashback } \\
\text { Packaging }\end{array}$ & $\begin{array}{l}\text { BP5 } \\
\text { BP6 } \\
\text { BP7 } \\
\text { BP8 } \\
\text { BP9 }\end{array}$ \\
\hline Place & Sales location. & $\begin{array}{l}\text { Channel } \\
\text { Location }\end{array}$ & $\begin{array}{l}\text { BP10 } \\
\text { BP11 }\end{array}$ \\
\hline Promotion & $\begin{array}{l}\text { Marketing communication to inform, } \\
\text { influence, and persuade consumers to } \\
\text { buy the product. }\end{array}$ & $\begin{array}{l}\text { Promotional media } \\
\text { Sales promotion }\end{array}$ & $\begin{array}{l}\mathrm{BP} 12 \\
\mathrm{BP} 13\end{array}$ \\
\hline Religiosity & $\begin{array}{l}\text { Individuals who are committed to } \\
\text { religion and teachings. Religious } \\
\text { commitment can influence consumers' } \\
\text { orientation regarding consumption } \\
\text { patterns and social behavior. }\end{array}$ & $\begin{array}{l}\text { Halal label } \\
\text { Leaving interest } \\
\text { Al-Qur'an } \\
\text { Prayer } \\
\text { Fasting } \\
\text { Mutual help } \\
\text { Honest } \\
\text { Giving } \\
\text { Da'wah }\end{array}$ & $\begin{array}{l}\text { RG1 } \\
\text { RG2 } \\
\text { RG3 } \\
\text { RG4 } \\
\text { RG5 } \\
\text { RG6 } \\
\text { RG7 } \\
\text { RG8 } \\
\text { RG9 }\end{array}$ \\
\hline Brand Image & $\begin{array}{l}\text { A rational and emotional perception of } \\
\text { consumers of a particular brand. }\end{array}$ & $\begin{array}{l}\text { Brand identity } \\
\text { Brand personality } \\
\text { Brand association } \\
\text { Brand behavior } \\
\text { Brand competence and benefit }\end{array}$ & $\begin{array}{l}\text { BI1 } \\
\text { BI2 } \\
\text { BI3 } \\
\text { BI4 } \\
\text { BI5 }\end{array}$ \\
\hline Brand Switching & $\begin{array}{l}\text { The intensity of the brand switching } \\
\text { carried out by the consumer for each time } \\
\text { of use or the brand switching level. }\end{array}$ & $\begin{array}{l}\text { Internal environment } \\
\text { External environment } \\
\text { Emotional response } \\
\text { Rational response }\end{array}$ & $\begin{array}{l}\text { BS1 } \\
\text { BS2 } \\
\text { BS3 } \\
\text { BS4 }\end{array}$ \\
\hline Brand Attitude & Positive attitude in the brand. & $\begin{array}{l}\text { Personal experience } \\
\text { Group associations } \\
\text { Others influence }\end{array}$ & $\begin{array}{l}\text { SK1 } \\
\text { SK2 } \\
\text { SK3 }\end{array}$ \\
\hline
\end{tabular}


H6 : Religiosity has a significant effect on brand image.

H7 : Brand image has a significant effect on brand attitude.

H8 : Religiosity has a significant effect on brand switching.

H9 : Brand image has a significant effect on brand switching.

H10: Brand attitude has a significant effect on brand switching.

The research will analyzes the suitability of Sharia about cosmetics products from $\mathrm{Nu}$ Skin and the factors that affect the brand switching of the cosmetics product with multi-level marketing. Moreover, some theoretical implications can be made based on the analysis results referring to Hair, Black, Babin, and Anderson (2013). It is regarding the model development used in the research. The development of this model aims to modify the existing models. Furthermore, the development of the model is expected to contribute to the knowledge of cosmetics marketers with Sharia-tiered direct sales system.

\section{METHODS}

The research applies a descriptive-quantitative approach. Descriptive analysis is used to determine respondents' characteristics. The samples of the research are Muslim consumers of $\mathrm{Nu}$ Skin who live in Jabodetabek. Then, 150 respondents are selected using the purposive sampling method, in which the sample unit is adjusted to certain criteria based on the research objectives.

Data collection from respondents is carried out with a structured questionnaire with a Likert scale via Google form. The questionnaire is filled in by the respondents themselves (self-report). Moreover, the questionnaire is divided into three parts: screening, profiling, and main questions related to the variables. The six variables in the research consist of WOM, marketing mix, brand attitude, brand image, religiosity, and brand switching. The research uses Structural Equation Modeling (SEM) to measure the relationship between variables. The operational definition for each variable can be seen in Table 1 .

\section{RESULTS AND DISCUSSIONS}

According to the Fatwa DSN MUI 75/DSNMUI/VI/2008, Sharia-tiered direct sales companies are legal and halal if the business scheme gets an operational permit from the relevant authorities and associations, the product has halal certification, the rights and obligations of the parties are transparent and fair as a great commission is given to distributors, and it is free from the practice of money games. In other words, it is free of uncertainty (gharar) and gambling (maisir).

Interviews with $\mathrm{Nu}$ Skin representative brand practitioner and executive brand partner obtain the information of Sharia review in Nu Skin. All Nu Skin products marketed in Indonesia already have halal certification from the Islamic Food and Nutrition Council of America (IFANCA) that LPPOM MUI has recognized for body care, facial skincare, and supplement. $\mathrm{Nu}$ Skin has also been registered as a member of the Indonesian Direct Selling Association (Asosiasi Penjualan Langsung Indonesia (APLI)). All contracts in the $\mathrm{Nu}$ Skin sales system are buying and selling. The contract conducted by the parties that transact in the Nu Skin sales system is the ijarahtijarah agreement. It means that the distributor and the owner of the goods try to get income. It implies that business in $\mathrm{Nu}$ Skin is not a money game. The sales system in $\mathrm{Nu}$ Skin has created a gap, and there is a royalty system used for distributors according to their contribution to the company. Then, the rule of law used in the brand Nu Skin sales system is La Dharara Wala Dhirara which means that it is not justified to make something that harms oneself or others.

The profile of respondents is shown in Table 2. The involved respondents are women $(92,7 \%)$ aged between 20 to 30 years $(51,70 \%)$. Moreover, they are enrolled in an undergraduate program (78\%). Most of them are private employees $(36 \%)$ and housewives $(30,7 \%)$.

Table 3 shows the purchase expenses over a specified period. Regarding cosmetics buying behavior, around $61,3 \%$ of the respondents spend less than $\mathrm{Rp} 500.000,00$ for $\mathrm{Nu}$ Skin products per month. Meanwhile, $27,3 \%$ of the respondents report the purchase expenditure between Rp500.000,00 and Rp2.000.000,00 per month.

Based on Table 4, it is clear that consumers of cosmetics products through multi-level marketing are more affected by WOM through their friends in purchasing $\mathrm{Nu}$ Skin products. As many as 70,7\% of respondents agree that they obtain information from their friends. Also, some respondents obtain information from family members $(10,7 \%)$ and social media $(16 \%)$. The remaining $(2,6 \%)$ is from other sources.

Suitability model test from Root Mean Square Error of Approximation (RMSEA), Goodness of Fit (GFI), Adjusted Goodness of Fit Index (AGFI), Incremental Fit Index (IFI), Normed Fit Index (NFI), Non-Normed Fit Index (NNFI), Comparative Fit Index (CFI), and Root Mean Square Residual (RMR) can be seen in Table 5. The overall value of the aspects of the conformity criteria is included in the good fit category. Hence, the overall model of the research is declared feasible. The results are obtained after the respecification indicates that the results of the overall model fit test are included in the good fit category.

GFI is a non-statistical measure with a range of values between 0 (poor fit) and 1 (good fit). High values in this index indicate that the model has a better fit. A GFI value of 1,00 indicates that the model is categorized as a good fit based on the results. Moreover, AGFI shows the recommended acceptance 
Table 2 Characteristics of Respondents

\begin{tabular}{|c|c|c|}
\hline Characteristics & Frequency & $\%$ \\
\hline \multicolumn{3}{|l|}{ Gender } \\
\hline Male & 11 & 7,3 \\
\hline Female & 139 & 92,7 \\
\hline \multicolumn{3}{|l|}{ Age } \\
\hline $20-25$ years & 20 & 13,3 \\
\hline $26-30$ years & 80 & 53,4 \\
\hline $31-45$ years & 42 & 28 \\
\hline$>45$ years & 8 & 5,3 \\
\hline \multicolumn{3}{|l|}{ Education } \\
\hline High School/ equivalent & 16 & 10,7 \\
\hline Diploma & 5 & 3,3 \\
\hline Bachelor degree (S1) & 117 & 78 \\
\hline Masters (S2) & 12 & 8 \\
\hline \multicolumn{3}{|l|}{ Profession } \\
\hline Government employees & 7 & 4,6 \\
\hline Private employees & 54 & 36 \\
\hline Entrepreneurs & 10 & 6,7 \\
\hline College student & 9 & 6 \\
\hline Housewife & 46 & 30,7 \\
\hline Brand Nu Skin Distributors & 24 & 16 \\
\hline
\end{tabular}

Table 3 The Purchase Expenses per Month

\begin{tabular}{lcc}
\hline Purchase Expenses & Frequency & \% \\
\hline$<$ Rp500.000,00 & 92 & 61,4 \\
Rp500.000,00-2.000.000,00 & 41 & 27,3 \\
Rp2.000.001,00-4.000.000,00 & 6 & 4 \\
$>$ Rp4.000.000,00 & 11 & 7,3 \\
Total & 150 & 100 \\
\hline
\end{tabular}

Table 4 Source of Product Information

\begin{tabular}{lcc}
\hline Source & Frequencies & $\mathbf{\%}$ \\
\hline Friends & 106 & 70,7 \\
Family & 16 & 10,7 \\
Social media & 24 & 16 \\
Others & 4 & 2,6 \\
Total & 150 & 100 \\
\hline
\end{tabular}


Table 5 Overall Model Fit

\begin{tabular}{clccc}
\hline No. & Goodness-of-Fit & Cut- off- Value & Results & After Elimination \\
\hline 1. & Root Mean Square Error of Approximation (RMSEA) & $\leq 0,08$ & 0,05 & Good Fit \\
2. & Goodness of Fit (GFI) & $\geq 0,90$ & 1,00 & Good Fit \\
3. & Adjusted Goodness of Fit Index (AGFI) & $\geq 0,90$ & 0,95 & Good Fit \\
4. & Incremental Fit Index (IFI) & $\geq 0,90$ & 1,00 & Good Fit \\
5. & Normed Fit Index (NFI) & $\geq 0,90$ & 1,00 & Good Fit \\
6. & Comparative Fit Index (CFI) & $\geq 0,90$ & 1,00 & Good Fit \\
7. & Non-Normed Fit Index (NNFI) & $\geq 0,90$ & 0,99 & Good Fit \\
8. & Root Mean Square Residual (RMR) & $\leq 0,1$ & 0,0017 & Good Fit \\
\hline
\end{tabular}

level if it has an equal or greater value than 0,90 . GFI and AGFI take into account the weighted proportion of the variance in a sample covariance matrix. AGFI value of 0,95 can be interpreted as a reasonable level. It means that the model can be accepted with a good level and included in the good fit category.

RMSEA is an index that can be used to compensate for chi-square statistics in large samples. The RMSEA value indicates the expected GFI when the model is estimated in the population. RMSEA value, which is smaller or equal to 0,08 , is a criterion of a close fit based on degrees of freedom. The results obtain the RMSEA value of 0,05 . It means the model is acceptable and included in the good fit category. Like the other measurement criteria, the RMR produces a smaller value than 0,1 . It shows a good model. Then, for IFI, it has the value of 1,00 , meaning the good model (good fit).

From the values obtained, the entire model built has a corresponding value (the goodness of fit statistics). The structural models have met the specified criteria, so the built model can explain the empirical information according to the collected data. The results of several criteria conclude the model of the goodness of fit, so the testing of theoretical hypotheses can be done. Evaluation of the measurement model for each variable based on SEM is shown in Figure 4 (see Appendices). It shows that the predetermined model can assess WOM, marketing mix, brand attitude, brand image, religiosity, and brand switching based on the used indicators.

The suitability test of the measurement model is done using validity and reliability tests. The suitability test of the measurement model after elimination can be seen in Table 6 (see Appendices). An indicator of the variable is valid when it has a more standardized loading factor value than the tolerable loading factor limit $(\geq 0,50)$ and a t-value above 1,96 . Based on the standardized loading factor diagram and the t-values diagram, all variables meet the validity requirements indicated by a standardized loading factor of more than 0,5 and a $t$-value above 1,96 . Those indicators are included in the significant category. However, the latent variable of religiosity has a standardized loading factor value that is less than the tolerable limit of the loading factor, which is 0,50 . It is on the indicator of always using halal products (RG1). It means that all the variables and indicators represent the developed latent construct well. It also shows that each variable is valid for measuring its latent construct, except the indicator of always using halal products (RG1).

Moreover, reliability is a measure of the internal consistency of the indicators of a construct. It shows the degree to which each indicator indicates a common construct or latent factor. The measurement results of the reliability test show that all Construct Reliability (CR) and Variance Extracted (VE) values meet the reliability requirements $(\mathrm{VE} \geq 0,5, \mathrm{CR}$ value $\geq 0,7$ ). VE values for each latent variable have a value of 0,5 . Those values are highly recommended. Table 7 (see Appendices) explains the value of CR and VE. Therefore, it can be concluded that the variables have good reliability or can measure the construct.

The results of the measurement model show that the overall model fits with the data. So, the results can be declared valid and reliable. The hypothesis in the research has been analyzed and tested by using the path coefficients in SEM. The results of the SEM indicate the effects of WOM on attitudes, WOM on brand image, marketing mix on attitudes, marketing mix on brand image, religiosity on brand image, brand image on attitudes, religiosity on brand switching, and brand image on brand switching. The path coefficient value, which is equal to or more than 0,05 , with a bigger value of $t$-value than 1,96, indicates a significant influence. Conversely, the path coefficient value, which is smaller than 0,05 , with a smaller $\mathrm{t}$-value than 1,96, means the insignificant influence. Table 6 (see Appendices) shows the mixed results of the hypotheses.

Based on the first hypothesis (H1) results, SEM analysis shows that the latent variable of WOM has no significant effect on the latent variable of brand attitude $(\beta=0,03)$. In Table 8 (see Appendices), it can be seen that the path coefficient is 0,03 , and the $\mathrm{t}$-value is 0,15 . These results indicate that the WOM has an insignificant effect on the brand attitude because the $t$-value does not exceed the significance requirement of 1,96. Hence, the results reject and do not support the first hypothesis. This hypothesis is 
not supported because it is assumed that the stronger the WOM is, the more impact it has on consumer attitudes. However, several researchers have shown that very negative WOM has a stronger impact on consumers. The existing literature lacks sufficient evidence to provide a more definite relationship between the power of WOM and the development of consumers' attitudes. The strong messages can hinder the true power of messages because they develop negative reactions in the recipients. The results are consistent with the research of Kudeshia and Kumar (2017), who showed the results that WOM affected brand attitude and, consequently, influenced purchase intention. The spending patterns of consumers, particularly decision-makers, have been affected to a substantial degree by the strong presence of brands on the web. WOM, one among the shape of product reviews, exercises extensive influence not only on the consumers' attitude towards the brand but also impacts their buying intentions. WOM, which is negative after a failed service or product, is more influential and has a greater impact on consumers than WOM, which is positive. Consumers are more willing to engage in negative WOM after service. Failure has a negative impact on attitudes.

For the second hypothesis (H2), the latent variable of WOM positively affects the latent variable of brand image $(\beta=0,26)$. The test results have a path coefficient value of 0,26 and a t-value of 3,23 . The t-value exceeds the significance requirement of 1,96 . It means that WOM has a direct and significant effect on brand image. Several previous studies are used to support the analysis results, resulting in the same hypothesis. It is in line with the previous research that the WOM in the form of product reviews posted on interactive social media has a strong effect on brand image, which will generate purchase intentions (Luong, Vo, \& Le, 2017).

In the third hypothesis (H3), the latent variable of the marketing mix has a positive effect on the latent variable of brand attitude $(\beta=0,37)$. The results show the path coefficient of 0,37 and a t-value of 2,15 . The t-value exceeds the significance requirement of 1,96. It explains that the marketing mix has a direct and significant effect on brand attitude. Hence, the results support the third hypothesis that the marketing mix has a positive and significant effect on brand attitudes. The results are consistent with Simanjuntak, Sumarwan, and Situmorang (2020) that marketing mix significantly affects brand attitude.

Based on the fourth hypothesis (H4) results, the latent variable of the marketing mix has a positive effect on the latent variable of brand image $(\beta=0,64)$. It is proven by the values of path coefficient of 0.64 and $\mathrm{t}$-count of 8,46 . The t-value exceeds the significance level of 1,96. It means that the marketing mix has a direct and significant effect on the brand image. The results are also supported by previous research with the same hypothetical results by Simanjuntak et al. (2020). They suggested that the marketing mix had a positive and significant effect on the brand image.
For the fifth hypothesis (H5), the latent variable of religiosity has a positive effect on the latent variable of brand attitudes $(\beta=0,17)$. The results are proven a path coefficient of 0,17 and a t-value of 2,06. The t-value exceeds the significance requirement of 1,96 . The results suggest a direct and significant effect of religiosity on brand attitude. These results are in line with previous research with the same hypothesis (Gunawan \& Ratnasari, 2018). They showed that religiosity had a positive and significant effect on brand attitude. It means that religiosity strengthens the relationship between brand name and brand attitude. Moreover, religious orientation affects the way consumers behave in choosing products and brands. Value propositions from halal labels and sales systems according to Sharia can affect consumers' attitudes in buying products.

Based on the sixth hypothesis (H6) results, The latent variable of religiosity has no significant effect on the latent variable of brand image $(\beta=0,04)$. It can be seen that the path coefficient value is 0,04 , and the $\mathrm{t}$-value is 0,97 . These results indicate that religiosity does not have a significant effect on the brand image because the t-value does not exceed the significance requirement of 1,96 . So, the sixth hypothesis is rejected. The hypothesis is not supported because Muslim consumers' attitudes may differ between brands from Muslim countries and western countries. The results are in accordance with the research of Dekhil, Jridi, and Farhat (2017). It is suggested that religiosity is one of the antecedents of the decision to participate in a boycott, and this decision has a negative effect on the consumers' attitude. Moreover, religiosity has a negative effect on buying imported products. It affects the brand image of imported products and purchasing decisions on halal brands or products.

For the seventh hypothesis (H7), the latent variable of brand image has no significant effect on the latent variable of brand attitude $(\beta=0,08)$. It can be seen that the path coefficient value is 0,08 , and the $\mathrm{t}$-value is 0,44 . These results indicate that the brand image does not have a significant effect on the brand attitude. The t-value does not exceed the significance requirement of 1,96. Therefore, the results do not support the hypothesis. However, the results are consistent with Ramesh, Saha, Goswami, and Dahiya (2019), showing a negative relationship between brand image, brand attitude, and brand perception. Brand image is based on experience, and the significant influence is from brand attitude on willingness to buy in the future. Brand in the consideration is evoked by positive attitudes trailing behind.

Based on the eighth hypothesis (H8) results, the latent variable of religiosity has no significant effect on the latent variable of brand switching $(\beta=-0,03)$. The path coefficient value is $-0,03$, and the $t$-value is $-0,37$. These results indicate that religiosity does not have a significant effect on brand switching because the $\mathrm{t}$-value does not exceed the significance requirement of 1,96. The results are in accordance with Ishak et al. (2019), suggesting no significant influence of 
religiosity on the intensity of brand switching.

In the ninth hypothesis 9 (H9), the latent variable of the brand image significantly affects the latent variable of brand switching $(\beta=-0,58)$. The path coefficient is $-0,58$, and the t-value is $-6,37$. The t-value exceeds the significance requirements of $-1,96$. The results are in line with Shabbir, Khan, and Khan (2017). The brand has become a necessary part of daily life. When the product becomes a brand, it promises quality, trust, and a distinct place in a range of choices. Brand image can corrode because of negative experiences or positive new information about substitute brands. Moreover, brand image makes consumers faithful with the product, irrespective of its price. Brand image has a positive and significant effect on brand switching. In detail, brand image has a positive effect on brand trust and brand loyalty. So, it reduces the intensity of brand switching.

Based on the tenth hypothesis (H10) results, the latent variable of brand attitude positively affects the latent variable of brand switching $(\beta=0,15)$. The results are proven by a path coefficient of 0,15 and a t-value of 2,14. The t-value exceeds the significance requirement of 1,96. The results align with Bozbay, Karami, and Arghashi (2018), showing a positive and significant effect of brand attitude on brand switching. Brand switching has a relationship with consumers' satisfaction derived from the products and is also connected to brand attitude, consumers' usage patterns, and product engagement. Brand love impacts brand attitude, and it will make brand loyalty and lead to WOM. Brand attitude is considered as an interposed variable and the impact on brand loyalty and WOM.

The research results indicate that two variables are not supported or have a direct or indirect negative relationship, namely WOM and religiosity towards brand switching. The other five variables, namely WOM, marketing mix, religiosity, attitude, brand image, positively correlate with brand switching. Through the results, it is expected that marketers obtain useful input. Thus, they can design strategies to build a positive attitude toward the marketing mix, attitude, and brand image.

There are several implications by examining WOM, marketing mix, and religiosity towards brand switching. First, Sharia-tiered direct sales of the $\mathrm{Nu}$ Skin conform with the Sharia review. All Nu Skin products marketed in Indonesia are halal and have good substance (thayyib) because it already has halal certification from IFANCA. Moreover, the contract is purely a trade agreement. The rewards follow the work and are free from the elements of gharar, maisir, and zholim. Second, WOM and marketing mix significantly affect the brand image. Thus, Nu Skin products that are reviewed and recommended by consumers may improve the brand image. Moreover, the marketing mix and consumers' religiosity significantly influence brand attitude. The marketing mix activities, such as product mix, price, place, and promotion, may improve brand attitude. Then, the higher religiosity is, the greater the consumers show brand attitude.
Third, brand attitude and brand image have a positive influence on brand switching. The good brand image and attitude of $\mathrm{Nu}$ Skin can encourage consumers to reduce the intensity of brand switching. However, WOM does not significantly influence brand attitude, and religiosity does not directly influence brand switching. Marketing strategies that marketers can use to increase loyalty through WOM are Product, Price, Place, and Promotion (4P). The marketers can maintain the halal label, include the halal logo on product packaging, and make attractive packaging to increase consumers' interest.

\section{CONCLUSIONS}

Based on the analysis, the research finds that most consumers who buy and use $\mathrm{Nu}$ Skin products are women of productive age (25-30 years old) who work as private employees and housewives. Most of them have a bachelor's degree. The descriptive results can be used as a reference for the target market of $\mathrm{Nu}$ Skin. Marketers can do direct selling by posting $\mathrm{Nu}$ Skin products on social media with interesting pictures, reviews, and explanations with the theme of busy housewives and private employees who are at work. Nu Skin consumers are most familiar with the products through their friends, and most of them buy facial skincare products. The research results indicate the influence of WOM on brand image. The marketers of $\mathrm{Nu}$ Skin products may use consumers' habits in accessing social media as a marketing strategy. The consumers read product reviews from their friends who have used $\mathrm{Nu}$ Skin products before. The more people review and recommend the products to others, the greater the consumers' interests are in buying brand $\mathrm{Nu}$ Skin products, and the smaller the intensity is involved in brand switching behavior.

Besides, the consumers' habit of accessing social media and reading product reviews has increased the brand image of $\mathrm{Nu}$ Skin. Consumers' perceptions of products form the brand image. Online reviews by old consumers describe the results of their perceptions after consuming them. Then, consumers who provide recommendations on a product will strengthen the brand image of the product, which also reinforces consumers' recommendations. Then, it will form a separate brand image in the eyes of consumers from excellence, strength, and product uniqueness. Therefore, the purchase intensity increases.

Based on the research results, four things need to be considered by cosmetics marketers with Shariatiered direct sales systems concerning the intensity of brand switching. First, the marketers maintain the halal label of Nu Skin products, which is the Islamic Food and Nutrition Council of America (IFANCA) recognized by LPPOM MUI. It is essential for manufacturers to put halal labels on product packaging. Thus, Muslim consumers get peace and understanding of the positive attitude of the Nu Skin. Furthermore, providing halal information on $\mathrm{Nu}$ Skin products in Indonesia will provide a good product image for the halal cosmetics 
market in Indonesia. It is also necessary to increase packaging on $\mathrm{Nu}$ Skin products to be more attractive to increase consumer buying interest.

Second, consumers of $\mathrm{Nu}$ Skin agree to buy the product because it matches the offered quality. However, it is also necessary to develop competitive pricing strategies, so prices of $\mathrm{Nu}$ Skin products can compete with other cosmetics products with the same sales system. Furthermore, there is a need for special supervision to maintain the same price level on general consumers. Therefore, there will be no difference in selling prices at the level of general consumers who may drop the product position in the market. Third, consumers of Nu Skin agree that purchasing channels through distributors are easily accessible. However, there is a need for distributors or sellers to force follow-up regularly because cosmetics products require a detailed explanation of the use and benefits continuously. Fourth, marketers are expected to promote with engaging and easy-to-remember media. Inculcating the brand image of $\mathrm{Nu}$ Skin through promotion with personal selling is more effective because the wrong promotion by members or buyers can bring down the product image. Furthermore, market testing for product development can be done at the same time during the transaction.

The research has been carried out by referring to the previous research. However, there are still some research limitations, including cosmetics products as the object of the research. It is only limited to $\mathrm{Nu}$ Skin and does not represent products from other brands. Therefore, the research results can only be implemented in $\mathrm{Nu}$ Skin products. Then, the latent variable of religiosity has homogeneous results. It is because the indicator of religiosity in the questionnaire still has normative answers. Based on the research that has been done, future research can use additional variables that have the potential for the marketing strategy and more detailed indicators of religiosity to produce non-normative answers from respondents.

\section{REFERENCES}

Antioco, M., \& Coussement, K. (2018). Misreading of consumer dissatisfaction in online product reviews: Writing style as a cause for bias. International Journal of Information Management, 38(1), 301310.

Bozbay, Z., Karami, A., \& Arghashi, V. (2018). The relationship between brand love and brand attitude. In $2^{\text {nd }}$ International Conference on Management and Business (pp. 8-9).

Cekindo. (2019). Registrasi kosmetik di Indonesia. Retrieved from https://www.cekindo.com/id/ layanan/registrasi-kosmetik-indonesia

Dekhil, F., Jridi, H., \& Farhat, H. (2017). Effect of religiosity on the decision to participate in a boycott: The moderating effect of brand loyalty-The case of Coca-Cola. Journal of Islamic Marketing, 8(2), 309328.
Direct Selling News (DSN). (2019). DSN announces the 2019 Global 100! Retrieved from https://www. directsellingnews.com/dsn-announces-the-2019global-100/

Elaziz, M. F., \& Kurt, A. (2017). Religiosity, consumerism and halal tourism: A study of seaside tourism organizations in Turkey. Tourism: An International Interdisciplinary Journal, 65(1), 115-128.

Global Business Guide Indonesia. (2016). Overview of Indonesian cosmetic sector: Growing domestic and export markets. Retrieved from www.gbgindonesia. com/en/manufacturing/article/2016/overview_of indonesian_cosmetic_sector_growing_domestic_ and export_markets_11593.php

Gunawan, $\bar{S}$., \& Ratnasari, R. T. (2018). Role of negative brand name perception and religiosity on brand attitude. In Increasing Management Relevance and Competitiveness (pp. 201-206).

Harun, A., Mahmud, M., Othman, B., Ali, R., \& Ismael, D. (2020). Understanding experienced consumers towards repeat purchase of counterfeit products: The mediating effect of attitude. Management Science Letters, 10(1), 13-28.

Hair, J. F., Black, W. C., Babin, B. J., \& Anderson, R. E. (2013). Multivariate data analysis. Pearson Education Limited.

Ishak, S., Omar, A. R. C., Khalid, K., Ghafar, I. S. A., \& Hussain, M. Y. (2019). Cosmetics purchase behavior of educated millennial Muslim females. Journal of Islamic Marketing, 11(5), 1055-1071.

Khasanah, U., \& Cahya, B. T. (2018). Brand switching produk kosmetik halal: Ditinjau dari aspek daya tarik iklan dan variety seeking. AKTSAR: Jurnal Akuntansi Syariah, 1(2), 199-214.

Kudeshia, C., \& Kumar, A. (2017). Social eWOM: Does it affect the brand attitude and purchase intention of brands? Management Research Review, 40(3), 310330 .

Luong, D. B., Vo, T. H. G., \& Le, K. H. (2017). The impact of electronic word of mouth on brand image and buying decision: An empirical study in Vietnam tourism. International Journal of Research Studies in Management, 6(1), 53-63.

Moreno, F. M., Lafuente, J. G., Carreón, F. Á., \& Moreno, S. M. (2017). The characterization of the millennials and their buying behavior. International Journal of Marketing Studies, 9(5), 135-144.

Ramesh, K., Saha, R., Goswami, S., \& Dahiya, R. (2019). Consumer's response to CSR activities: Mediating role of brand image and brand attitude. Corporate Social Responsibility and Environmental Management, 26(2), 377-387.

Septiani, S., \& Indraswari, R. (2018). Faktor-faktor yang memengaruhi perilaku konsumen produk kosmetik halal di Kota Bogor. Jurnal Manajemen dan Organisasi, 9(1), 59-73.

Shabbir, M. Q., Khan, A. A., \& Khan, S. R. (2017). Brand loyalty brand image and brand equity: The mediating role of brand awareness. International Journal of Innovation and Applied Studies, 19(2), 416-423. 
Simanjuntak, M., Sumarwan, U., \& Situmorang, A. D. (2020). The effect of marketing mix and brand image on customer loyalty of remixed mortar. Independent Journal of Management \& Production, 11(2), 450472.

Sözer, E. (2019). The effect of social media mix on brand switching intention: The mediating role of risk perception. Journal of Yaşar University, 14(53), 7486. 


\section{APPENDICES}

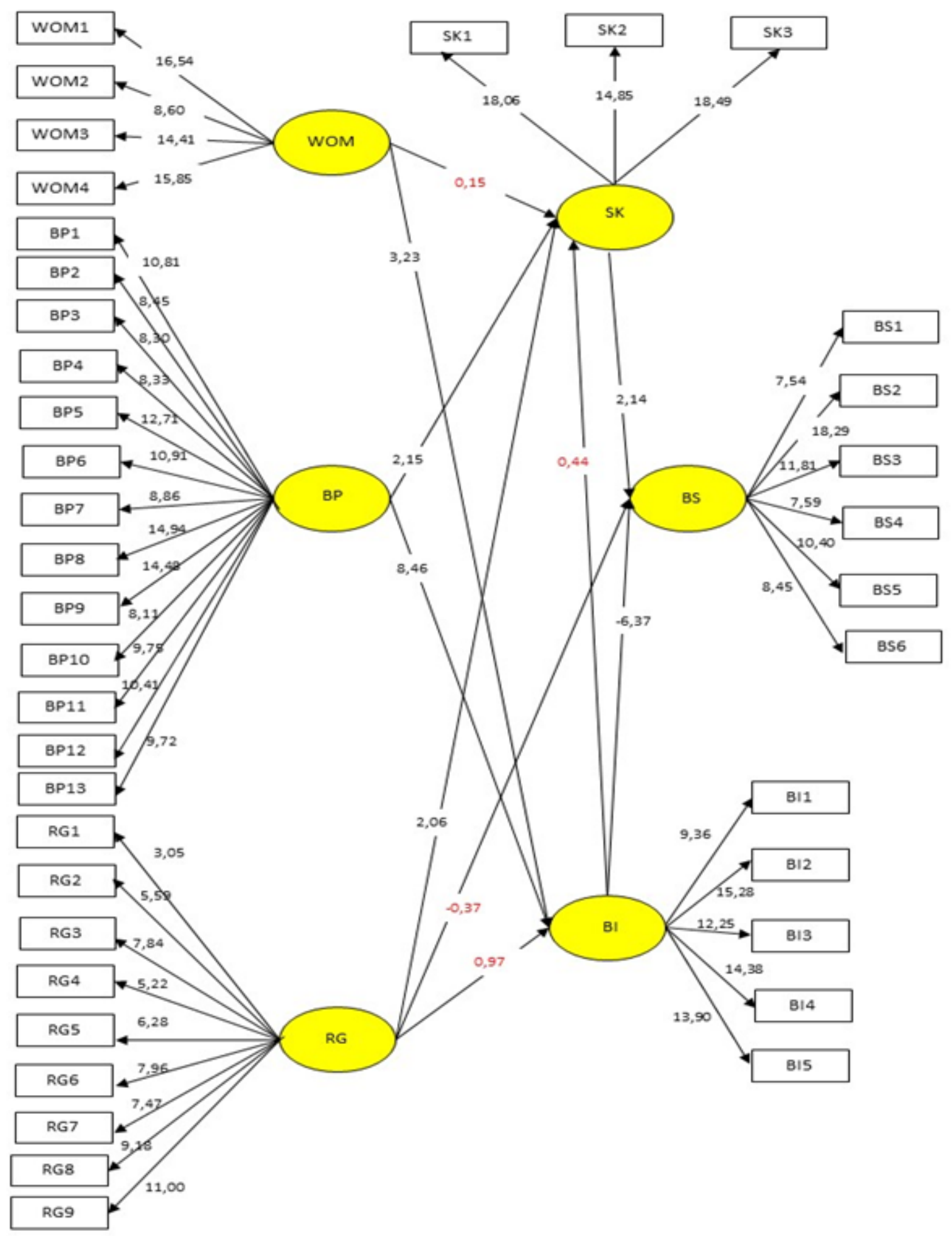

Figure 4 Structural Equation Modeling (SEM) 
Table 6 The Results of Measurement Model Fit

\begin{tabular}{|c|c|c|c|c|}
\hline Latent Variables & Codes & Loading Factor & T-Value & Conclusions \\
\hline \multirow[t]{4}{*}{ WOM } & WOM1 & 0,90 & 16,54 & Valid \\
\hline & WOM2 & 0,63 & 8,60 & Valid \\
\hline & WOM3 & 0,79 & 14,41 & Valid \\
\hline & WOM4 & 0,91 & 15,85 & Valid \\
\hline \multirow[t]{13}{*}{ Marketing Mix } & BP1 & 0,83 & 10,81 & Valid \\
\hline & BP2 & 0,72 & 8,45 & Valid \\
\hline & BP3 & 0,73 & 8,30 & Valid \\
\hline & BP4 & 0,64 & 8,33 & Valid \\
\hline & BP5 & 0,72 & 12,71 & Valid \\
\hline & BP6 & 0,71 & 10,91 & Valid \\
\hline & BP7 & 0,61 & 8,86 & Valid \\
\hline & BP8 & 0,90 & 14,94 & Valid \\
\hline & BP9 & 0,86 & 14,48 & Valid \\
\hline & BP10 & 0,75 & 8,11 & Valid \\
\hline & BP11 & 0,66 & 9,75 & Valid \\
\hline & BP12 & 0,79 & 10,41 & Valid \\
\hline & BP13 & 0,80 & 9,72 & Valid \\
\hline \multirow[t]{3}{*}{ Brand Attitude } & SK1 & 0,99 & 18,06 & Valid \\
\hline & SK2 & 0,99 & 14,85 & Valid \\
\hline & SK3 & 1,00 & 18,49 & Valid \\
\hline \multirow[t]{5}{*}{ Brand Image } & BI1 & 0,67 & 9,36 & Valid \\
\hline & BI2 & 0,92 & 15,28 & Valid \\
\hline & $\mathrm{BI} 3$ & 0,85 & 12,25 & Valid \\
\hline & BI4 & 0,93 & 14,38 & Valid \\
\hline & BI5 & 0,79 & 13,90 & Valid \\
\hline \multirow[t]{9}{*}{ Religiosity } & RG1 & 0,29 & 3,05 & Invalid \\
\hline & RG2 & 0,50 & 5,59 & Valid \\
\hline & RG3 & 0,62 & 7,84 & Valid \\
\hline & RG4 & 0,52 & 5,22 & Valid \\
\hline & RG5 & 0,51 & 6,28 & Valid \\
\hline & RG6 & 0,71 & 7,96 & Valid \\
\hline & RG7 & 0,68 & 7,47 & Valid \\
\hline & RG8 & 0,78 & 9,18 & Valid \\
\hline & RG9 & 0,71 & 11,00 & Valid \\
\hline \multirow[t]{6}{*}{ Brand Switching } & BS1 & 0,61 & 7,54 & Valid \\
\hline & $\mathrm{BS} 2$ & 0,93 & 18,29 & Valid \\
\hline & $\mathrm{BS} 3$ & 0,81 & 11,81 & Valid \\
\hline & BS4 & 0,61 & 7,59 & Valid \\
\hline & BS5 & 0,75 & 10,40 & Valid \\
\hline & BS6 & 0,66 & 8,45 & Valid \\
\hline
\end{tabular}


Table 7 The Values of Construct reliability (CR) and Variance Extracted (VE)

\begin{tabular}{lcc}
\hline Variable & Construct Reliability & Variance Extracted \\
\hline WOM & 0,88 & 0,66 \\
Marketing Mix & 0,94 & 0,56 \\
Brand Attitude & 0,99 & 0,98 \\
Brand Image & 0,92 & 0,70 \\
Brand Switching & 0,87 & 0,53 \\
Religiosity & 0,85 & 0,54 \\
\hline
\end{tabular}

Table 8 Hypothesis Testing Results

\begin{tabular}{clccc}
\hline Hypothesis & \multicolumn{1}{c}{ Variable } & $\begin{array}{c}\text { Standard } \\
\text { Solution }\end{array}$ & T-Value & Conclusion \\
\hline H1 & WOM $\rightarrow$ Brand Attitude & 0,03 & 0,15 & Insignificant \\
H2 & WOM $\rightarrow$ Brand Image & 0,26 & 3,23 & Significant \\
H3 & Marketing Mix $\rightarrow$ Brand Attitude & 0,37 & 2,15 & Significant \\
H4 & Marketing Mix $\rightarrow$ Brand Image & 0,64 & 8,46 & Significant \\
H5 & Religiosity $\rightarrow$ Brand Attitude & 0,17 & 2,06 & Significant \\
H6 & Religiosity $\rightarrow$ Brand Image & 0,04 & 0,97 & Insignificant \\
H7 & Brand Image $\rightarrow$ Brand Attitude & 0,08 & 0,44 & Insignificant \\
H8 & Religiosity $\rightarrow$ Brand Switching & $-0,03$ & $-0,37$ & Insignificant \\
H9 & Brand Image $\rightarrow$ Brand Switching & $-0,58$ & $-6,37$ & Significant \\
H10 & Brand Attitude $\rightarrow$ Brand Switching & 0,15 & 2,14 & Significant \\
\hline
\end{tabular}

